\title{
The Scottish Medical Service Emergency Committee
}

In 2011, the College received funding from the Wellcome Trust to catalogue our deposited collections. Earlier this year, as part of that project, cataloguing was completed on the papers of the Scottish Medical Service Emergency Committee which were deposited in 1920. These papers contain a wealth of information and provide an important research resource for anyone interested in the history of the impact of the First World War on the civilian population.

One immediate consequence of the outbreak of the First World War in 1914 was the withdrawal from civil practice of around 300 medical men who held commissions in the Royal Naval Reserve, Royal Army Medical Corps or combatant units. The chairman of the Scottish Committee of the British Medical Association (BMA) called a conference to consider what steps could be taken to alleviate this problem. It met on 12 August 1914 and appointed a Committee 'for the purposes of assisting to meet the immediate difficulties in regard to medical practice among the civil population which have arisen'.The Committee was named the Scottish Medical Service Emergency Committee and was composed of the presidents of the three Scottish Royal Colleges, the Deans of the Faculties of Medicine of the Universities of St Andrews, Glasgow, Aberdeen and Edinburgh and eight members elected by the conference.

The early work of the committee, to the end of 1914, was in the civil sphere, establishing the number of practitioners in Scotland through the Medical Directory and the Scottish Insurance Commission, and their distribution using the Scottish divisions of the BMA. It acted as a clearing house, matching those areas in need of medical services to medical practitioners able to do the work. In March 1915 the War Office issued its request for 'every qualified man who is physically fit and willing to serve'. To prevent this from putting a further strain on civilian medical services a system was devised whereby the names of all medical applicants from Scotland were sent by the Army Medical Services to the Scottish Insurance Commission who conferred about the possible ramifications with the Committee. If an appointment would have caused too much upheaval, it was refused, or more usually, delayed until extra support could be put in place. Later that year, once the Committee was recognised as a recruiting agency by the War Office, Army Medical Services and the Committee dealt directly with each other.

A second medical conference was held, also in 1915, to consider the need for additional officers for the Royal Army Medical Corps. A resolution was passed on 7 July
1915 to provide at least 400 medical men for the Army. The Scottish Committee of the BMA asked for its branches to submit returns on how many practitioners each could spare.' In order to prevent a conflict between the Scottish Committee's military recruitment and the Emergency Committee's civil safeguarding, it was decided that both roles should be undertaken by the Emergency Committee. To that end the BMA passed its returns to the Emergency Committee to administer. The Emergency Committee in turn undertook its own survey thereby cementing the latter's role in the recruitment process (Figure I). ${ }^{2}$ This survey was made possible by another development in 1915: the establishment of Local War Committees. They were able to provide information on particular cases, helping the Emergency Committee in Edinburgh to make informed decisions. The collection contains a large amount of correspondence with these committees, adding local detail to the national picture. ${ }^{3}$

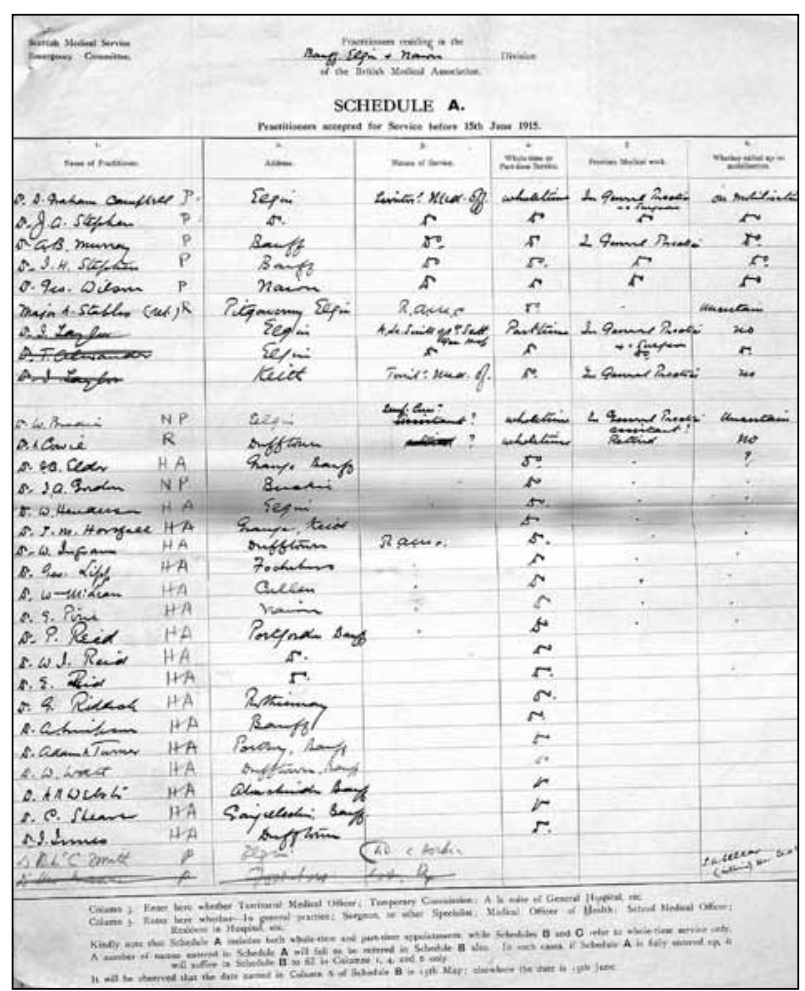

FIGURE I Schedule of medical strength. ${ }^{2}$

Another important aspect of the Emergency Committee's work was informing the public of changes in medical provision in their areas. The collection holds a number of examples of these, ${ }^{4,5}$ as well as notices produced by the Insurance Committees. ${ }^{6}$ The profession also broke with tradition in allowing advertising of changes to practices in local newspapers. 
The registration and intimation forms that were required under the National Registration Act 1915 make up a sizeable part of the collection. ${ }^{7}$ These differ from the earlier surveys as the information was sought directly from the individuals concerned and not from local committees. These forms were sent to every doctor in the country and the information gathered included whether the doctor had already served in the Royal Army Medical Corps or was intending to serve. Such information provides a valuable genealogical resource for anyone with ancestors who were doctors.

A complication arose in 1916 with the passing of the Military Service Act which provided for compulsory military service for all single men between the ages of 18 and 40. Initially doctors were uncertain whether this applied to them but clarification eventually came in March with an Army Instruction allowing that any practitioner who had registered as willing to accept a commission could not be called up. This also served to encourage those doctors who had not yet registered to send in their form.

Another general call up came in April 1917 but the Committee successfully negotiated with the War Office for a smaller number of doctors (Figure 2). Statements showing the number of doctors resident in each area also provided the number of patients per doctor in the different divisions. ${ }^{8}$ The small number of doctors explained why the Committee was so concerned about the impact of a general call up on medical provision for the public.

Under an extension of the Military Service Act, the Emergency Committee also took on a tribunal role for appeals by practitioners. Doctors appealing their call up could fill out an application for exemption. ${ }^{9}$ Although not

\section{REFERENCES}

I British Medical Association War Emergency Committee divisional returns. Collection of the Scottish Medical Service Emergency Committee, Royal College of Physicians of Edinburgh Archives, $\mathrm{SMC} / 3 / 2$

2 Schedules of medical strength. Collection of the Scottish Medical Service Emergency Committee, Royal College of Physicians of Edinburgh Archives, $\mathrm{SMC} / 3 / 3$.

3 Correspondence with the secretaries of the local war committees. Collection of the Scottish Medical Service Emergency Committee, Royal College of Physicians of Edinburgh Archives, SMC/2/2.

4 Suggested form of announcement. Collection of the Scottish Medical Service Emergency Committee, Royal College of Physicians of Edinburgh Archives, SMC/4/ I/35.

5 IV - individual cases. Collection of the Scottish Medical Service Emergency Committee, Royal College of Physicians of Edinburgh Archives, SMC/6/2/4.

6 Lists of doctors. Collection of the Scottish Medical Service Emergency Committee, Royal College of Physicians of Edinburgh Archives, SMC/3/7/3.

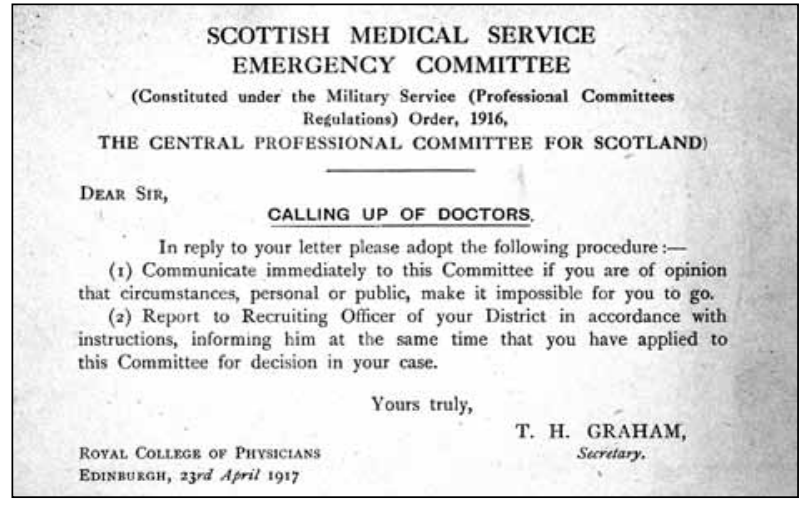

FIGURE 2 Advisory card for calling up of doctors. ${ }^{10}$

every doctor appealed, for those who did, these forms provide further information to complement the registration form.

Armistice came in November 1918 by which time 2,349 Scottish civilian practitioners had served in the forces. The process of demobilisation began. The Committee was keen to prioritise the release of doctors to areas where the shortage was most severe. Local War Committees were also encouraged to make their own cases for the return of practitioners, particularly those who had worked in hospitals or in public office. The result was the lists of officers selected for priority release which were sent to the Ministry of National Service at the end of the year." Although releasing doctors on a priority basis was not always practical, the War Office did take notice of the Committee's lists. As demobilisation continued, the Committee realised that it no longer had a role to play and it was dissolved on 31 December 1919.

\section{- A Scott, Archivist}

7 Registration and intimation forms. Collection of the Scottish Medical Service Emergency Committee, Royal College of Physicians of Edinburgh Archives, SMC/3/4/I.

8 Statements showing the number of doctors resident in each area. Collection of the Scottish Medical Service Emergency Committee, Royal College of Physicians of Edinburgh Archives, SMC/3/6.

9 Applications for exemption. Collection of the Scottish Medical Service Emergency Committee, Royal College of Physicians of Edinburgh Archives, SMC/3/4/5.

10 Advisory card for calling up of doctors. Collection of the Scottish Medical Service Emergency Committee, Royal College of Physicians of Edinburgh Archives, SMC/4/I/39.

II List of officers selected for priority release. Collection of the Scottish Medical Service Emergency Committee, Royal College of Physicians of Edinburgh Archives, SMC/3/9/1. 